\title{
Estonia: A Positive PISA Experience
}

\author{
Gunda Tire
}

\begin{abstract}
According to Programme for International Student Assessment (PISA) run by Organization of Economic Cooperation and Development (OECD), Estonian education system stands out as a high performing system where students from different socio-economic backgrounds achieve high results. In PISA 2018 Estonian students ranked first in reading and science and third in mathematics among the OECD countries. What has Estonia done to be at the top of the PISA league tables? There are many aspects that have contributed to the success of Estonian education. The following chapter will look at the historical background, describe the factors, policies and conditions that have contributed to the current educational landscape that has attracted considerable attention from all over the world.
\end{abstract}

\section{Estonia in the Spotlight}

PISA is a household name in Estonia. Everybody knows something about it, schools never refuse to participate, and every new round of PISA data release is expected with certain amount of curiosity. Estonians by nature are very self-critical and without PISA they would never admit that Estonia has one of the best performing education systems in the world.

PISA 2018 data was released on December 3, 2019 and it turned out to be almost like a national holiday. The press conference led by the minister of education and research was streamed online, all the main media channels were present, and the news spread fast-according to PISA 2018, Estonian education system is the best in Europe and among the best performing systems in the world! The evening news on national TV devoted more than 10 min to covering PISA results, journalists had interviewed students and teachers from different urban and rural schools, and everybody felt that they had personally contributed and were very proud of their achievement.

Teachers, students and school principals received official acknowledgement on job well done by the whole society and the establishment.

\footnotetext{
G. Tire $(\bowtie)$

Education and Youth Authority, Tallinn, Estonia

e-mail: gunda.tire@harno.ee

(C) The Author(s) 2021 
PISA has put Estonia in the spotlight and in 2019 the top three positive topics about Estonia in the foreign media were: success stories about the digital society, genome research in Tartu University and outstanding results of Estonian students in PISA 2018.

\section{Estonia and Its Education System}

Estonia is a small country with 1.3 million inhabitants. It covers 45,000 square kilometres and is larger than, for example, the Netherlands, Denmark or Switzerland. It is located on the Eastern shores of the Baltic sea in the Northern part of Europe and has borders with Russia on the East and Latvia on the South. It has beautiful, pristine nature, it is rich in forests and has more than 1500 islands along its coastline. The official language is Estonian which belongs to rare Finno-Ugric family of languages. Estonian population comprises $69 \%$ of Estonians, $25 \%$ of Russians and $6 \%$ of other ethnic groups (Statistics Estonia 2017). The language division is reflected also in the education system. There are two types of schools-one with Estonian as the language of instruction, the other where instruction is mainly conducted in the Russian language.

In order to better understand the origins of Estonian education system, we should take a step back and look at the countries' rather turbulent history.

For centuries, the territory of Estonia has been almost always conquered by some great powers. The start of formal education can be dated back to thirteenth century when German rulers opened the first church schools in Estonia but did not really influence literacy or numeracy rates of the population. More systematic approach to education opened to people only after Reformation, which happened simultaneously in Europe and in the Baltic countries, once Tallinn became part of the Hanseatic trade route. In the seventeenth century the northern part of Estonia became under the rule of Swedish Kingdom, consequently, agriculture and education were organised according to the Swedish model. Some influences of "Good old Swedish times" are present even today. On the Swedish initiative, the academic gymnasiums were opened in Tallinn in 1631 and Tartu in 1630, the University of Tartu was established in 1632. The school in Tallinn, dedicated to the Swedish king Gustav Adolf, is still functioning today and is one of the best schools in Estonia.

The church taught a large part of peasantry children to read from the second half of seventeenth century. The idea that all children should be educated, regardless of their social standing was applied (Ruus 2002). In the beginning of eighteenth century during the Great Northern War with Russia, the territory of Estonia was conquered by the Russian empire. Because of the lasting war and devastating plague, population diminished nearly tenfold, the only university and a lot of schools were closed. However, Baltic Germans were the ones who de facto ruled in Estonia as they had a strong stand in Czar's court in St. Petersburg and Russians lacked administrative power to manage their remote territories themselves. Russification appeared for a short time at the end of the nineteenth and beginning of twentieth century. 
The rules and education reforms implemented in the tsarist Russia applied formally also to Estonian elementary schools. According to census in 1897, the level of literacy among Estonians was 80\% which was the highest in Russian empire (Lees 2016). The presence of two foreign cultures, German and Russian, encouraged the development of Estonian national identity in the nineteenth century.

Estonia became an independent state in 1918 and introduced free, compulsory and public education for all. The new country quickly implemented prevailing European ideas about the democratic nature of schools, mother-tongue instruction, secondary schools, developing talents of every child, supporting children's initiative and developing extracurricular activities. All this was cut short in 1940 when Estonia together with other Baltic countries was occupied by the Soviet Union. Estonia lost about fifth of its population due to the losses in the Second World War, many fled to the West from the Soviet regime and many were deported to Siberia and never returned.

Education during the Soviet area remained in Estonian, although massive instruction of Russian language as "a language of friendship" was added to the curricula. Undisguised ideology was added even to math and science lessons; however, history and social sciences suffered the most. Foreign languages were poorly taught with minimal hours and learning materials, heavily saturated with Soviet ideology. The goal was to keep people in isolation from the rest of the world and foster the growth of Homo Sovieticus as a new species. In schools, strong emphases were put on subjects such as maths and science due to the military needs. The Soviet regime tried hard to keep people in isolation from the West, however, Estonia had a privilege to peek through the Iron Curtain due to its proximity to Finland $(80 \mathrm{~km})$. People could watch the Finnish TV and since Finnish and Estonian languages are related, many Estonians mastered the Finnish language independently and followed the life in the West with the help of Finnish television.

The breakthrough for Estonian education was Estonian Teacher's Congress that took place in 1987. The Independence of the Estonian state was re-established in 1991 and Estonian teachers were the voice of freedom four years prior to that. The teachers in 1987 demanded a new, independent, Marxism-Leninism ideology free curriculum for secondary schools, they formed committees consisting of teachers, scientists, university professors, etc. A lot of help was received from Estonians living abroad who were well organised and paid a lot of attention to supporting education in Estonia. Many Estonians whose parents had emigrated during the Second World War, returned and helped in re-arranging the system.

Because of the language similarities and exchanges with Finnish universities, Finnish education system and practices had their influence on processes in Estonia. At that time Finland had already for two decades followed the comprehensive school system. Estonians looked at their curricula, teaching materials and practices and learned from their neighbours.

After intensive work, the curriculum for newly independent Estonia's education was ready and introduced to schools in 1989 , two years before the country officially regained its independence.

The curriculum created in 1989 was reformed in 1996. If until then teachers were given quite a detailed description of what they should teach in their subjects, 
then after the reform more attention was on what students should know and be able to do (output-oriented curriculum). Teachers were provided with contemporary ideas, popular in European countries, such as competences-based curriculum, general and cross-curricular competences, subject strand competences. This created a bit of confusion and resistance among teachers, but more than twenty years later we can say that it was a very innovative and positive change that was implemented. The next curriculum revision was done in 2002. The national curriculum is updated approximately every ten years and it states the learning outcomes that students should master during different stages of their formal education.

The education system is mostly public, the private schools comprise $11 \%$. The description of Estonian education system is reflected in Fig. 1.

Estonia follows the comprehensive school system and compulsory education, called the "basic education", lasts from grades 1 to 9 . The comprehensive school (ühtluskool in Estonian) is aimed to provide all students with the best education, regardless of their background. The first streaming into academic or vocational tracks takes place after grade 9 when students are 15-16 years old. For some historical
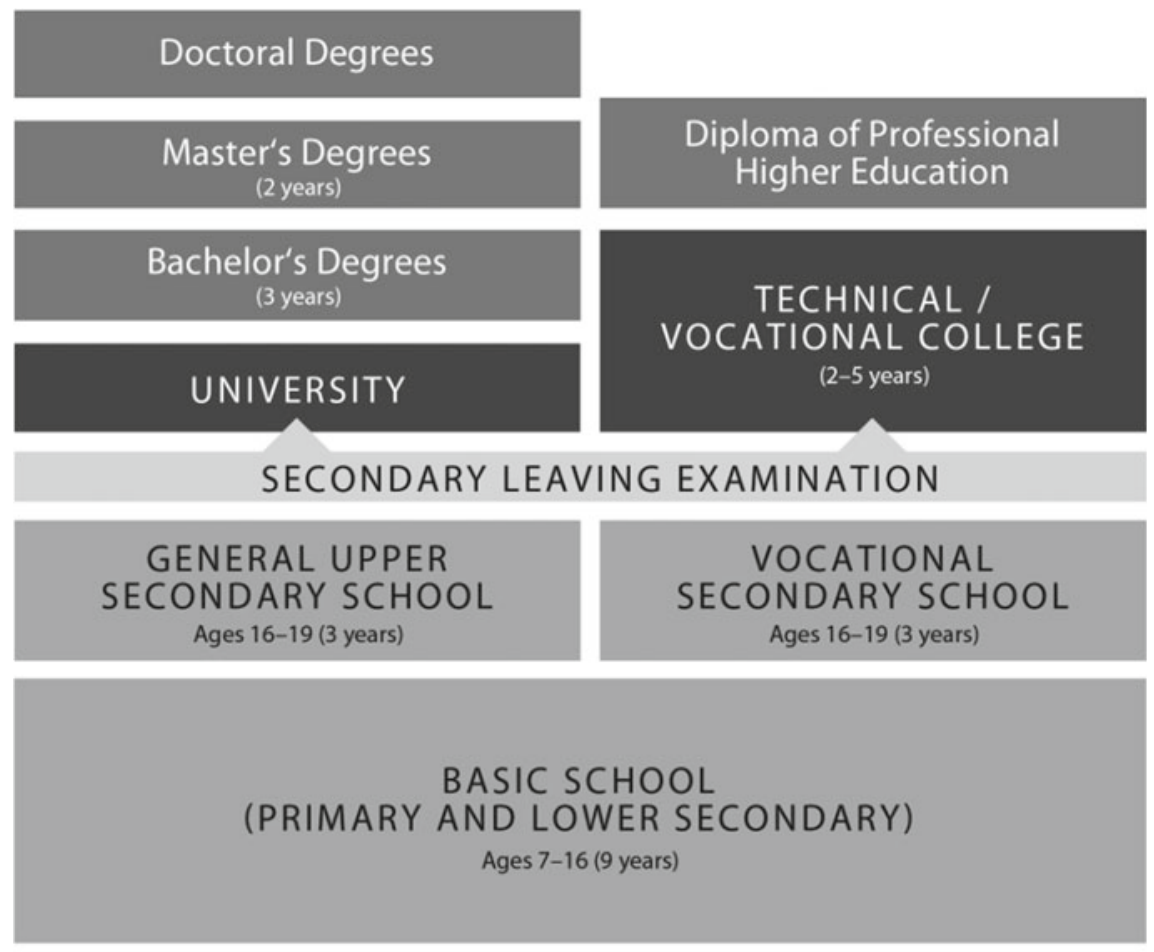

\section{EARLY CHILDHOOD EDUCATION Ages 3-7 (Not Compulsory)}

Fig. 1 Education system in Estonia 
reason, majority of students, partially encouraged by their families, choose academic (upper secondary) path, around $25 \%$ of students opt for vocational education.

Estonian primary education system is based on a strong pre-school education. Around $94 \%$ of children attend kindergartens and children start school at the age of 7. Preschools similarly to general education schools follow the state curriculum. The idea is to provide also young children with a playful, competence based, guided and structured plan for their activities. Although children start school at a relatively late age of 7, many of the activities that in other countries are done at school, Estonian children do in kindergarten in a more playful and relaxed environment. Most children know how to read and write when they start first grade at school.

Schools are generally owned by the local municipalities and consequently enjoy quite extended autonomy. All schools can decide on their culture, goals and the focus of studies. They can specialize in science, languages or any other subject. They follow the state curriculum, which is the framework for developing school curriculum as the national curriculum leaves space for the school to develop their identity. Principals can hire and fire teachers, decide on how to allocate the budget and evaluate the needs for teacher training. Teachers decide on the textbooks and teaching methods that they consider appropriate and would like to use in their lessons. There are basically no school inspectors, interference from the state in school matters is only case based, for example, if there has been a complaint on some matter.

It was also decided back in the nineties that all teachers must have a master's degree to work at school. Teachers used to have master's degree equivalent diplomas already in the Soviet times and it seemed only natural that this requirement should remain.

\section{What is Estonia's Experience in International Assessment Studies?}

It had been slightly more than a decade since the breakoff from the Soviet Union and complete reconstruction of its education system when Estonia started to participate in the international large-scale assessments.

The first international assessment Estonia participated was Trends in International Mathematics and Science Study (TIMSS) in 2003. The results were surprising. Estonian students were seventh in the international rankings and many people assumed that this must be a happy accident. Estonia never repeated TIMSS, but instead joined PISA in 2006. Since then, it has participated in all consequent PISA cycles. The other large-scale international survey Estonia has taken part is the OECD Teaching and Learning International Survey (TALIS) for teachers in 2008, 2013 and 2018. Student readiness as future citizens has been assessed by International Civic and Citizenship Education studies in 2009 and 2016 run by International Association for the Evaluation of Educational Achievement (IEA). Estonia has also been part of the OECD Programme for the International Assessment of Adult Competencies 
(PIAAC) which is a survey on adult skills in literacy, numeracy, and problem solving in technology rich environment. In 2018 Estonia participated in the OECD International early learning and child well-being study (IELS) with a focus on 5-year-old children.

The high rankings in PISA kept repeating and scores have been increasing in some areas of assessment. Estonians went through a positive "PISA shock", their critical nature would not believe that they have "a rather decent school system" and every time before new PISA data release the question in the air is "have we started to fall?".

\section{What Does PISA 2018 Say About the Student Performance in Estonia?}

When exploring different education systems, a significant and important factor is to note how much each country invests and spends on its education. Undoubtedly education needs resources, but high level of resources does not immediately result in high student performance (OECD 2019a). The Estonian case in PISA 2018 shows that high results can be achieved with less money. Estonia spends on education $30 \%$ less than other OECD countries. Nevertheless, it ranked first among the OECD countries in reading literacy and science and was third in mathematics. The mean score in reading of 523 points was statistically not different from the results of Macau (China) (525 points), Hongkong (China) (524 points), Canada (520 points), Finland (520 points) and Ireland (518 points). If the general message from the OECD is rather pessimistic about little or no improvement in student performance since the beginnings of PISA, then Estonia has shown positive improvement in reading and mathematics and has kept stable (and high) results in science. The improvement in reading is mostly due to the decreasing number of low performing students and the increase of the top performers. Altogether $89 \%$ of Estonian students have reached baseline level of proficiency in reading (OECD mean is 77\%). Between 2009 and 2018 the share of top performing students (levels 5 and 6) has increased by almost 8 percentage points. The performance gap between boys and girls has decreased from 44 points in 2009 to 31 points in PISA 2018 (OECD mean 30 points). The gender gap decreased in PISA 2015 when the test was moved from the paper to computer-based test. Figure 2 shows the trends of Estonian student performance in reading, maths and science over different PISA cycles.

There has been a slight improvement in mathematics. In PISA 2018, for the first time Estonia ranked right after the high-ranking Asian countries with a score of 523 points, which is statistically similar to the results of Japan, Korea and the Netherlands. $89.8 \%$ of Estonian students have reached the baseline level in mathematics and $15.5 \%$ of students are top performers on levels 5 and 6 . Boys perform slightly better than girls with 9 score points, which is a statistically significant difference. 


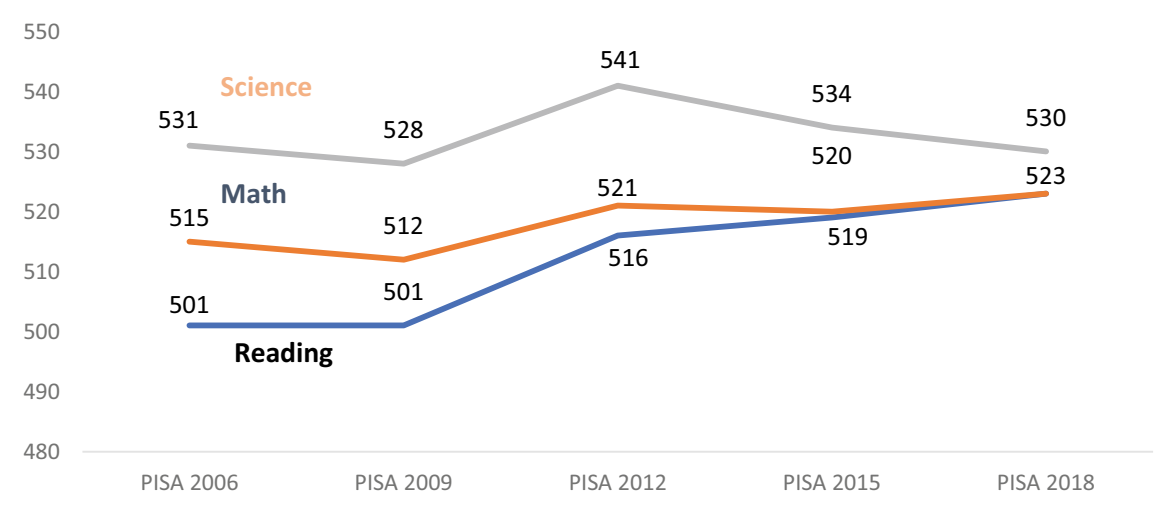

Fig. 2 Performance trends for Estonia

If countries had to pick, which is their favourite domain among the PISA assessed subjects, then Estonians would pick science. For some reason, scores in science have always been higher than in other domains. In PISA 2018 Estonian students scored 530 points in science, which is statistically indistinguishable from results of Japan with 529 points. If in previous PISA cycles, there was no gender gap in student performance, then in PISA 2018, for the first time, there is a statistically significant 5-point difference in favour of girls. Altogether $91.2 \%$ of Estonian students have reached the baseline level in science (OECD 78\%) and there are 12.2\% of students at the two highest levels of performance. This share has slightly decreased and again for the first time there are more girls performing at level 5 .

Figure 3 shows the shares of students at different levels of reading proficiency in PISA 2009 and 2018. It can be observed that in PISA 2018 the share of low performing students (below level 2) has decreased, whereas there has been an increase in the numbers of the top performing students (levels 5 and 6).

If the overall picture of Estonian student performance is very positive, then looking more closely in how different groups of students perform, there is some room for improvement. As already mentioned, the Estonian population comprises of $69 \%$ of Estonians and 25\% of Russians. Both groups of schools are treated equally. They receive funding, based on the same principles, follow the same national curriculum, etc. Through PISA we have learned that there is a considerable gap in achievement between the two groups. Russian schools have a good command of the basic skills and knowledge; however, they are less successful in the application, and PISA is all about the application of knowledge in real life situations. The gap between Estonian and Russian speaking students is 42 points in reading and science, 29 points in mathematics. The gap points out that there are more low performers and less high performers among the Russian students. At the same time the results of the Russian speaking students are above the OECD mean and it is a very good performance. However, in comparison with their peers in Estonian schools the gap persists. In PISA it is often referred that 39 points equals to one year of schooling. Why is there such a gap between the groups? We have tried to research both groups and can 


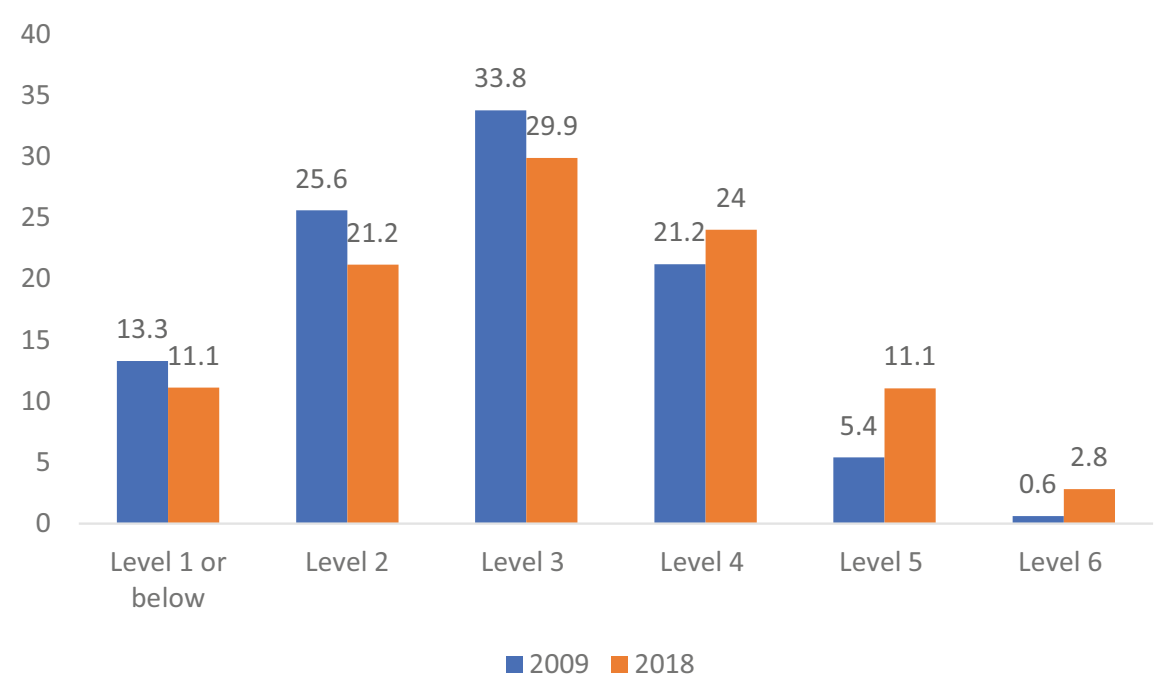

Fig. 3 Percentage of students at different levels of reading proficiency in PISA 2009 and 2018

mark the differences, but it is difficult to name the reason and fix it. There has been a strong suggestion from the political parties that Estonia should not maintain the education system with two languages and merge the schools which would lead to better integration of the society. Currently it has not been done yet.

\subsection{Educational Equity}

Another important aspect that describes the quality of education is equity. Estonia follows the comprehensive school model, where all students follow similar education path until the end of compulsory education (grade 9). The first streaming to academic and vocational tracks takes place at the end of basic school, when students are at the age of 16 . Moreover, grade repetition is not commonly practiced. It is believed that struggling students should be noticed early enough, and they should be helped while they are with the same age group peers.

PISA has consistently shown that Estonian education system manages to provide education for all students regardless of their socio-economic background. In fact, it is uncommon to classify schools according to the composition of the students and divide them as socially advantaged or disadvantaged. Only $6.2 \%$ of variation in reading scores could be explained by the student's socio-economic background (12\% in OECD). As in all countries, there is a significant difference (61 points) in average reading performance between students with high and low socio-economic background (99 points in OECD countries) (OECD 2019b). Students who come from poor families get financial help, which is granted by the social systems of the state. 
All students receive free hot lunch, some schools provide also a breakfast. For some of the disadvantaged students the school lunch might be the only hot meal of the day they get.

In Estonia, education by law is for free, unless the parents decide otherwise and choose private schools for their children. Apart from free services, such as lunch, textbooks, school transport, students get supporting services if needed. Many schools have their own psychologist, speech therapist, social pedagogue as a part of their staff. Smaller schools get those services from a state-run network that extends all over the country. Many students stay at school after the lessons are over. They use classrooms to do homework under teacher supervision or participate in extracurricular activities such as sports, art or computer clubs, which are often free and provided by the school.

Estonian school manages to compensate for what has not been provided to children at home and students from disadvantaged families often achieve high results. In PISA we call them "resilient students". Altogether $7.4 \%$ of students with disadvantaged background have reached the top levels of performance (2.9\% in OECD countries). Moreover, $15.6 \%$ of Estonian students with disadvantaged background belong to the best performing $25 \%$ of students. In fact, the mean score of students from the bottom quarter of socio-economic status is 497 points. This score is above the OECD average and shows that the poorest students in Estonia manage to perform better than the top quarter with the most affluent background in many countries. This proves that if a student is born poor, it necessarily does not have to stay that way and the school system is able to contribute to social mobility, care and develop potentially everybody to high levels. At the same time, $16 \%$ of Estonian students from disadvantaged socioeconomic background have not reached the baseline level of proficiency, whereas in the OECD countries this share of students is $36 \%$.

\subsection{Student Well-Being}

PISA is following the general trend of other international and national assessments in paying more and more attention to aspects of school climate, student well-being and learning habits.

In recent years, student well-being has been high in the listing of national policy priorities in Estonia. Therefore the "soft outcomes" from PISA 2018 are analysed with care. Already in two consecutive PISA cycles students were asked the following question: "How satisfied with your life in general are you these days?" Students are given a scale from "one" to "ten", "one" being the lowest and "ten" the highest level of life satisfaction. Although the general life satisfaction has fallen by $5 \%$ in the OECD countries since PISA 2015, Estonian students scored on average 7.19 (7.04 for the OECD countries). Estonia together with Finland, Germany and France show high levels of performance and relatively high levels of life satisfaction. Although $70 \%$ of Estonian students are satisfied with their life (67\% in OECD countries), $89 \%$ feel often happy and 9\% always feel sad (OECD 2019c). 


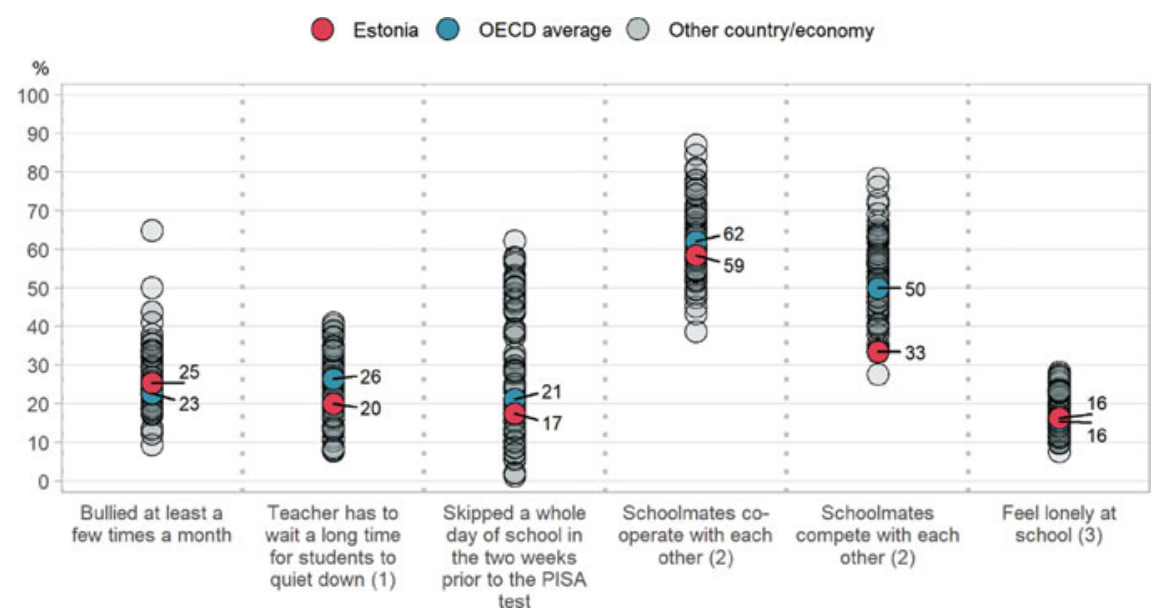

Fig. 4 Estonian School climate (Source OECD, PISA 2018 database)

How is life satisfaction related to reading performance? In general, Estonian data does not show any correlation between life satisfaction and reading performance. However, the data represents an interesting phenomenon. The lowest results in reading are for those students, who reported the highest levels of life satisfaction.

The biggest influence on student's well-being at school is exposure to bullying. $25 \%$ of Estonian students experience some sort of bullying and that slightly exceeds the corresponding levels in other OECD countries (23\%). There is better discipline and less skipping school when compared to other countries as can be seen in Fig. 4. Students value cooperation more than competition, but in comparison with other countries, the reported cooperation and competition levels are rather low (see Fig. 4).

\section{What is a Teacher in Estonia Like?}

In order to understand the key player - the teacher in the education system, we should have a glimpse at TALIS, the OECD Teaching and Learning International Survey. TALIS gives voice to teachers and school principals. The survey studies around 4000 teachers and principals from 200 schools per country. It explores issues about initial teacher training and continuous professional development, provides an overview of practiced teaching methods and different manifestations of classroom climate, etc. It also asks the teachers about their satisfaction levels with their job and how they feel about their profession. Estonia has participated in TALIS survey three times (TALIS 2008, 2013, 2018).

According to TALIS 2018 data, $86 \%$ of Estonian teachers are female and with an average age of 49 . The average age of teachers across OECD countries and economies is 44 . Altogether $54 \%$ of teachers (OECD average is $34 \%$ ) are aged 50 and above 
and this is the prime issue of sustainability of Estonian education system (OECD 2019d). Within the next decade there will be an urgent need to renew the workforce. Teachers in Estonia are very experienced and $81 \%$ of teachers have received all required formal qualifications. They report positive classroom environment, which is also in good concordance with the student reporting from PISA 2018.

Estonian teacher is inclined to follow more traditional, already well-established practices in their everyday work. Altogether $86 \%$ of lesson time is spent on teaching and learning. This exemplifies more effective time management than $78 \%$ of average in OECD countries. If over the past five to ten years, in most of the countries the actual teaching and learning time has decreased in about a half of the countries, then in Estonia it has increased with one percentage point. Teachers assess students' progress regularly, but they do not use that much the more modern approaches where students evaluate their own progress. In Estonia student self-evaluation is used only by $28 \%$ of teachers, in OECD countries $41 \%$.

$98 \%$ of teachers and $100 \%$ of principals have attended some sort of professional development activity during the year of survey. The areas where Estonian teachers expect to get more additional training are related to ICT skills, teaching in multicultural or multilingual settings and teaching students with special educational needs.

\section{What Policy Measures Have Supported Us Along the Way?}

Current legal framework of education, as a successor to pre-war existing Estonian Republic legal framework, was established in 1990s after the end of Soviet occupation. The main goal of initiated reforms was to liberate education from the burden of Soviet ideology and set the foundations for modern education system. As already described, the first steps were to find a common understanding of a new curriculum, write corresponding textbooks and retrain teachers. Many of the educational institutions went through restructuring and name restoration/change.

In the mid 1990s the Open Estonia Foundation (allied with Soros Foundation) played an important role in promoting ideas of free and independent schools. They trained school principals and launched the project on quality management system in Estonian schools.

In the 1990s the following main laws on education were adopted:

- The Law on Education of the Estonian Republic (1992) which outlined the general principles in education and its availability.

- The Law on Basic and Upper Secondary Schools (1993) described the grounds of operating and governing municipal basic and upper secondary schools.

- The National Curriculum (1996) provided a framework for all educational establishments regardless the language of instruction. Since then schools are supposed to develop their own curricula, based on the national curriculum. The national 
curriculum lists the compulsory subjects with a syllabus and states the number of lessons for each subject. The new curriculum was outcome oriented: it described knowledge, skills, attitudes and values - all together as competences, which were to be mastered in the learning process. The national curriculum was updated in 2011, splitting the curricula for basic schools and upper secondary schools into two different curricula. More detailed attention was designated to development of subject strand competences, general competences (adopted from corresponding EU framework) and cross-curricular competencies that all teachers should include in their subject lessons. The curriculum is updated approximately every ten years. - In 1997 the external evaluation system was established.

Since education in Estonia is mostly free and paid by the taxpayer, the assumption is that the state needs to know how well the money is spent. The goal of the external evaluation is to see how well students have mastered the learning goals from the national curriculum at different levels of study. External assessments are conducted at the end of grades 3 and 6. The tests cover Estonian language (or Estonian as second language for Russian medium schools) and mathematics. In addition, one other subject is tested in grade 6 on rotating bases in different years. It can be foreign languages, social sciences or science. Externally developed tests with corresponding marking schemes are administered to these grades. Tests are sample based and compulsory for $10 \%$ of schools, but since schools find them a valuable tool of quality measurement, they volunteer and administer them to their students outside the compulsory sample. Already for several years the grade 6 tests are computer based. Paper based tests are gradually disappearing. The goal is to have all national tests and examinations transferred to computer-based assessment by 2021.

At the end of compulsory education, in grade 9, students take three exams. Test forms and marking schemes are centrally provided, but the marking takes place at school by the subject teacher. The requirements for finishing the basic school consist of centralized examinations in mathematics, Estonian language, one freely chosen subject by the student (from a list of 10 subjects) and a completed research project organized by the school. The national modal grade for PISA is grade 9 and the test is administered to students approximately one month before they take these school leaving exams.

At the end of upper secondary school, grade 12 students take three centrally set and centrally marked national examinations that are also valid for entering universities or other higher educational establishments. Students should pass national examinations in Estonian or Estonian as a second language, mathematics (two different curricula are offered with different number of learning hours and corresponding exams), and in a foreign language, prepared by foreign examination companies. In addition to centralized examinations, students are required to pass a school exam, and conduct an independent research project in the topic of their interest.

Another school quality control instrument for school strategic development is school internal self-evaluation. It is compulsory and has been in use for more than a decade. During the self-evaluation process schools must analyse their past achievements from many different aspects and set goals for the future. 
An interesting project that had a huge impact on Estonian education system and society in general was initiated by the former president of Estonia Toomas Hendrik Ilves in 1996. The project was called "Tiger leap" and its goal was to provide all Estonian libraries and schools with internet and computer classrooms. The prime activity of the project was to provide know how and competence for incorporation of the technology in everyday life (using ID card, internet banking, reading online news and sending e-letters). This overarching project was very helpful in the digitalization of the society and Estonia has managed to achieve remarkable results. Now Estonia is among the most digitalized societies in the world with vast number of online services provided to its citizens. Almost everything can be done online-casting a vote in elections, filing a tax return or registering a childbirth, etc.

The demand for digitally educated citizens has put a significant pressure also on the education system to teach digital competence and this has been a high priority in state policies. Schools have integrated a variety of digital solutions and employed education technologists to support teachers in orienting in the jungle of education technology (educational programs, smartboards, robotic kits) and use the digital solutions in their lessons.

On the state level there are different databases that give access to information about schools and their quality of teaching. Schools have access to free digital textbooks and assessment banks, school administration software. All schools use some version of E-school system for communicating information about student's achievement, absences, homework, notices and exchanging information between schools and home.

Estonian education system was "upgraded" in 2014 when the government adopted the Estonian Lifelong Learning Strategy 2020 (Estonian Ministry of Education and Research 2014). The strategy document set out five priority areas for development.

1. Change in the approach to learning or focus on student centred learning. Each learner at all stages and types of learning should be provided with education that supports their individual and social development. The goal stresses the need to acquire appropriate learning skills, foster creativity and entrepreneurship.

2. Competent and motivated teachers and school leadership. This priority focuses on extensive teacher training and evaluation of teachers and headmasters.

3. Concordance of lifelong learning opportunities with the needs of labour market. Lifelong learning opportunities and career services that are diverse, flexible and of good quality should result in an increasing number of different age people with professional or vocational qualifications and in increasing overall participation in lifelong learning across Estonia.

4. A digital focus in lifelong learning. Modern digital technology is used for effective learning and teaching. The focus is on improvement in the IT skills of general population and grant access to the new generation of digital infrastructure.

5. Equal opportunities and increased participation in lifelong learning. Equal opportunities for lifelong learning should be created for every individual.

All goals were described in more detail, and indicators of measurement were attached. Data from national and international assessments intend to estimate if the 
goals have been reached. One of the key indicators about the top achievers is used from PISA and if the goal set in 2014 was to have $10 \%$ of students to be top performers in reading by 2020 then PISA 2018 shows that the goal has been achieved. There are $13.9 \%$ of students at the top levels of proficiency. The goals for mathematics and science were set slightly higher than the PISA 2018 results.

Substantial funding jointly with co-financing of structural funds of the European Union was added to support the implementation of the strategy.

The first goal gears the education away from the more traditional way of teacher centred teaching towards more progressive student-centred educational approach. As we know from TALIS 2018, Estonian teachers use less frequently those approaches if compared with teachers in other OECD countries despite the government priority. This again shows the consequences of autonomy of school system where schools and teachers are free to choose the teaching methods and apply what they feel most appropriate in their teaching.

The strategy document also marks the change from traditional summative assessment towards more child centred formative assessment that should support individual learning and development. According to legislation, the goal of external assessment is to give students, parents, schools, school administrators and the state an objective and comparative feedback to the learning objectives, stated in the national curriculum, as well as provide an input for formation of education policy (Basic and Upper Secondary Schools Act $§ 34)$.

To support every student more effectively, the proposed policies suggest using digital technologies more effectively. This complies with the digital focus of the strategy document. The Ministry of Education and Research has launched the development of innovative digital assessment tools. There are mixed opinions about the effectiveness of digital technologies in the educational process. PISA has repeatedly shown that those educational systems that use technology extensively in the study process, show poorer achievement results (OECD 2015). The opinion in Estonia is that ignoring technology and not involving it in the study process is disempowering students from participation in digital society. Digital devices are here to stay. They will be more user friendly in the future and we must learn to use them smartly in favour of student learning. The use of technology could be made more effective with additional teacher training. We see from PISA 2018 data that Estonian students feel that they are digitally advanced, and technology leaves a positive impact on the quality of their life.

Lots of effort and funding is put into the development of computer based "diagnostic tests" that would enable teachers to detect what students already know and what are their gaps in a specific topic or skill. Diagnostic tests are developed in most subjects along with collections of tasks and sets of digital learning materials. The assessment system is moving towards more precise measuring and reporting on subscales and measuring of value added. In addition, non-cognitive tests such as tests in social-emotional and digital competencies have been developed and already administered to several student cohorts. New tests have been developed with the help of experts from universities. 
The lifelong learning strategy document recommends the state to collect evidence about student development and wellbeing. As a result, in 2015 the decision was made to create an instrument (questionnaire) to measure student well-being. The same year the theoretical framework was developed, and the survey instruments were piloted in 2016 and 2017. The first full scale student well-being survey was administered in 2018 for grades 4, 8 and 11. In order to widen the picture, teachers and parents of the surveyed students were included in the study. Separate surveys were administered also to pre-schools, vocational schools and academic branch of educational establishments. The goal of the study is to get the big picture at the system level and provide each individual school with comparative reports about the general well-being and school climate in the context of national average. Each school is given a detailed report of indicators, concerning general wellbeing of their students, teachers, and parents. It also points out the problematic areas of the school that need attention (Ministry of Education and Research 2019). Schools use this data as an input for evidence-based self-development and quality improvement. The creation of centralised wellbeing measurement tool has spared schools from inventing their own wellbeing questionnaires and added the quality and comparability dimension.

\section{How Are Policy Measures Reflected by International Comparison Studies?}

PISA has affected Estonian education in a positive way. It has captured the picture of the education landscape since 2006 for five times. So far Estonia has not changed its education policy measures with a goal to excel in PISA outcomes. All the changes are a strive to improve and advance in line with the demands of the constantly challenging and changing world.

Table 1 is an attempt to summarise different policy measures and explain, how they are mirrored in assessments on national level.

\section{In a Nutshell: What is the Secret of Estonian Success?}

There have been tremendous changes in Estonian education system since 1990. Several post-soviet countries have asked the question-we all had the same starting platform, what did you do differently? There is no clear-cut answer to this question. Estonia has pursued the system of equity by treating every student equally, regardless of their background trying to provide the best learning conditions for all. Schools have enjoyed a lot of autonomy for decades; they have been very little disturbed by school inspectors. At the same time, there has been a strong strive to improve from within, to provide the best education for each child. This started with the introduction of mandatory school self-assessment as schools have been obliged to evaluate their 


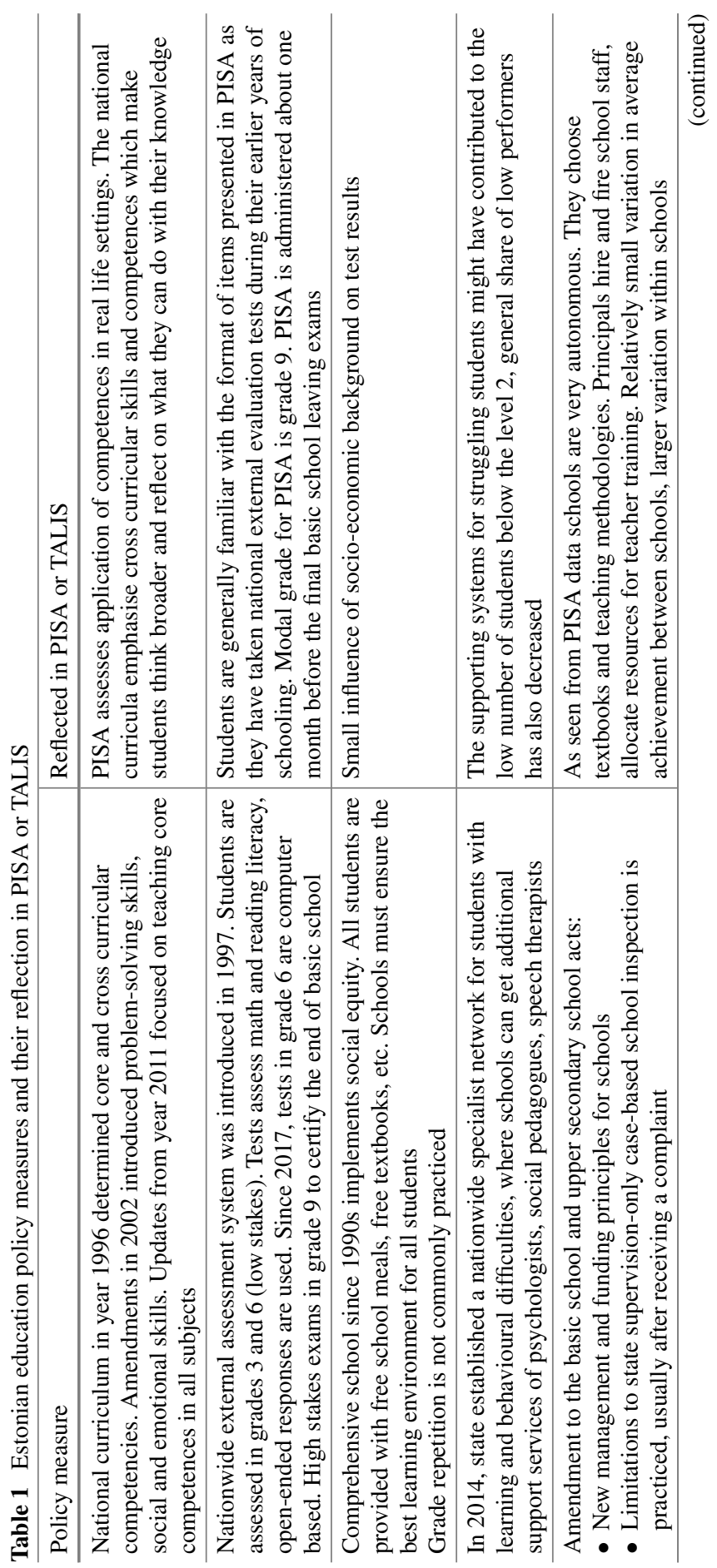




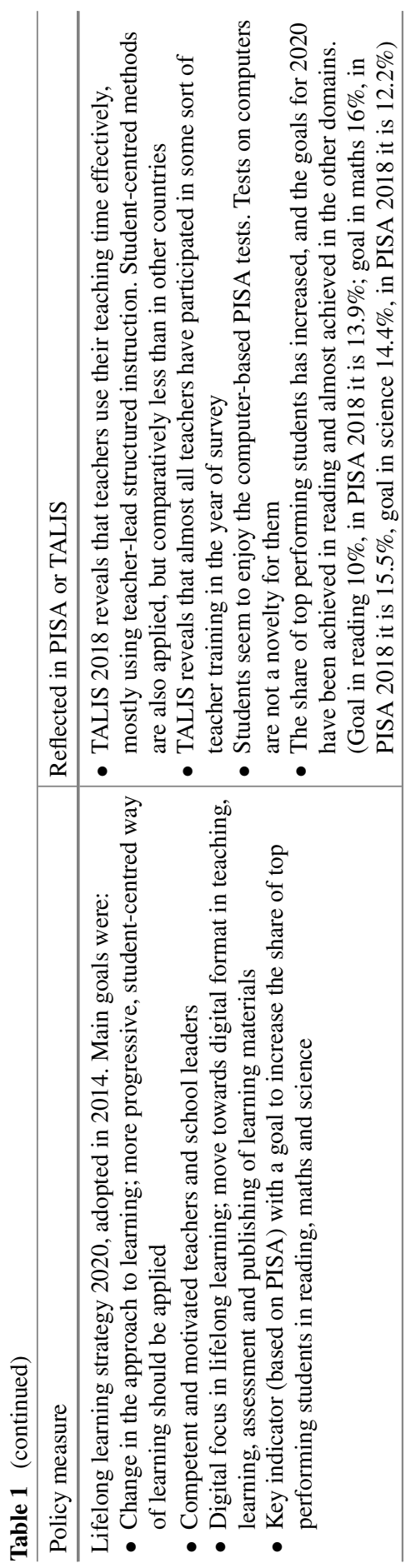


activities, set plans and visions for the future. Schools have received substantial funding to renovate or build new infrastructure and have created pleasant learning atmosphere.

In Estonia, like in many other countries, the aging of the population is a reality and it has reflected in the decline of the student numbers. In response to that school optimization has taken place all over the country. Some schools have been closed, others merged or reformed. This has created many emotions and put pressure on schools to improve. They must have a vision for future and come up with new solutions in order to survive. Schools have been very active in participating in different projects, in gaining international experience, for example, in getting exchange students and teachers. Teachers have access to in-service courses and training programmes free of charge. They have joined subject teacher networks to be constantly updated on important matters and actively exchange opinions. Schools offer variety of opportunities for using digital technology.

Estonian school curricula are based on the principle that students should have a broad worldview. Apart from languages, maths and science, many schools teach coding and robotics, starting already from the first grade. At the same time, the curriculum includes creative subjects such as music, art and physical education as mandatory subjects for all. Under physical education the school can decide to teach dance to all students or ski in the forest in case there is snow.

All schools have a technology class where they teach their children how to cook in well-equipped kitchenettes and knit a sock or cut woodwork. Usually all those practical skills are mastered by boys and girls alike in mixed groups. Making a dish, where everybody is responsible for certain ingredients and do their fair share during the preparation, is a good example of a typical common project that involves skills like cooperation, problem-solving, and everybody is goal oriented.

Estonians, by nature, are critical towards themselves as well as towards others. Their motto in life is that "it could always be better." The criticism is probably the driving force for improvement.

Effective education is served with a subtle balance between tradition and innovation, rigor and freedom, group and the individual (Robinson and Aronica 2016). Estonian schools might be slightly more traditional, the cognitive skills as well as the development of the soft skills are very much valued. It is widely agreed that school should be a place where students feel safe, happy, challenged and motivated to become well equipped future citizens. Estonian policy makers have set out to invent the next education strategy for year 2030, which should be more geared towards individual learning paths.

Well, what is the secret of Estonian success? Marc Tucker put it this way: "The fact that Estonia is among the top performers in PISA does not appear to be the result of education policies pursued since Estonia gained its independence, but rather the result of hundreds of years of political, social and educational development which ended up supporting a strong commitment to education as well as a tradition of very high education standards, very demanding curriculum, high quality examinations built directly on the curriculum, highly educated teachers, and most of the other drivers of high performing national education systems" (Tucker 2015). 


\section{References}

Basic and Upper Secondary Schools Act. Retrieved from https://www.riigiteataja.ee/akt/131122 015015.

Estonian Ministry of Education and Research. (2014). The Estonian Lifelong Learning Strategy 2020. Retrieved from https://www.hm.ee/sites/default/files/estonian_lifelong_strategy.pdf.

Estonian Ministry of Education and Research. (2019). Rahulolu haridusega. Retrieved from https:// www.hm.ee/et/rahulolu.

HITSA strategy for 2018-2020. Retrieved from https://www.hitsa.ee/about-us/news/hitsa-strategyfor-2018-2020-supports-increase-in-digital-competencies-in-the-society-as-a-whole.

Lees, M. (2016). Estonian Education System 1990-2016: Reforms and their impact. https://4liberty. eu/wp-content/uploads/2016/08/Estonian-Education-System_1990-2016.pdf.

Organisation for Economic Cooperation and Development. (2015). Students, computers and learning: Making the connection, PISA. Paris : OECD Publishing. https://doi.org/10.1787/978 9264239555-en.

Organisation for Economic Cooperation and Development. (2019a). PISA 2018 results: What students know and can do (Vol. 1). Paris: OECD Publishing. https://doi.org/10.1787/5f07c754-en.

Organisation for Economic Cooperation and Development. (2019b). PISA 2018 results: Where all students can succeed (Vol. 2). Paris: OECD Publishing. https://doi.org/10.1787/b5fd1b8f-en.

Organisation for Economic Cooperation and Development. (2019c). PISA 2018 results: What school life means for students' lives (Vol. 3). Paris: OECD Publishing. https://doi.org/10.1787/acd788 51-en.

Organisation for Economic Cooperation and Development. (2019d). TALIS 2018 results: Teachers and school leaders as lifelong learners (Vol. 1). Paris: OECD Publishing. https://doi.org/10.1787/ 1d0bc92a-en.

Robinson, K., \& Aronica, L. (2016). Creative schools. UK: Penguin Books.

Ruus, V.-R. (2002). The history of Estonian education-The story of the intellectual liberation of a nation. https://www.estonica.org/en/Education_and_science/The_history_of_Estonian_educ ation_\%E2\%80\%94_the_story_of_the_intellectual_liberation_of_a_nation/.

Statistics Estonia. (2017). Minifacts about Estonia 2017. https://www.stat.ee/publication-2017_m inifacts-about-estonia-2017.

Tucker, M. (2015). Tucker's Lens: Estonia: Unsung Heroine of the Baltic, but.... https://ncee.org/ 2015/03/tuckers-lens-estonia-unsung-heroine-of-the-baltic-but/.

Gunda Tire is PISA national project manager for Estonia since 2007. She works at Education and Youth Authority which is a government organization under the auspices of the Ministry of Education and Research. Her responsibilities include preparation, implementation and dissemination of PISA survey in Estonia. She has also been involved in other international educational projects. Gunda has been the editor for four national PISA reports, worked with schools and media as well as other stakeholders to disseminate PISA in Estonia and beyond. She has been a frequent speaker at educational conferences in Estonia and abroad, she has also received numerous delegations from all over the world and shared insights about Estonian education system. 
Open Access This chapter is licensed under the terms of the Creative Commons Attribution 4.0 International License (http://creativecommons.org/licenses/by/4.0/), which permits use, sharing, adaptation, distribution and reproduction in any medium or format, as long as you give appropriate credit to the original author(s) and the source, provide a link to the Creative Commons license and indicate if changes were made.

The images or other third party material in this chapter are included in the chapter's Creative Commons license, unless indicated otherwise in a credit line to the material. If material is not included in the chapter's Creative Commons license and your intended use is not permitted by statutory regulation or exceeds the permitted use, you will need to obtain permission directly from the copyright holder.

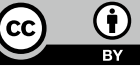

